\title{
PEMULIHAN STOK TANGKAPAN PERIKANAN TERIPANG DI KEPULAUAN SERIBU: SUATU PENDEKATAN EKOSISTEM
}

\author{
Restocking of Sea Cucumbers Fishery in Kepulauan Seribu: An Ecosystem Approach
}

Oleh:

Am Azbas Taurusman1, Dadang Shafrudin², Tri Wiji Nurani³, Didin Komarudin ${ }^{4}$

Departemen Pemanfaatan Sumberdaya Perikanan, FPIK-IPB. azbas@ipb.ac.id

2 Departemen Pemanfaatan Sumberdaya Perikanan, FPIK-IPB.dshafrudin@yahoo.com

3 Departemen Pemanfaatan Sumberdaya Perikanan, FPIK-IPB. triwiji@hotmail.com

${ }^{4}$ Departemen Pemanfaatan Sumberdaya Perikanan, FPIK-IPB. didinkomarudin@apps.ipb.ac.id

*Korespondensi:azbas@ipb.ac.id

Diterima: 18 Mei 2018; Disetujui: 26 Oktober 2018

\begin{abstract}
Kepulauan Seribu known as Thousand Islands is one of the sea cucumbers producing centers in Indonesia. Sea cucumber has been considered as one of the fishery export commodities with high selling prices. In the last two decades, the catch has been indicating a serious declining. The high intensity of catching and habitat degradation are two main factors that threaten the sustainability of sea cucumber fisheries. In order to recovery the stock, a restocking program in frame of ecosystem approach to fishery has been piloted in Thousand Islands, Jakarta. This research covers the bio-technical aspects of sea cucumber fisheries in an integrated manner with the ecosystem approach. There were several steps in conducting the restocking study, namely the study of habitat status and feasibility, preparation of maintenance sites for biota, seed spreading, monitoring and evaluation. A well coordination and collaboration with local institutions (Kepulauan Seribu National Park) was needed to build previously. The results of the study indicated that efforts to restore sea cucumber fisheries should be integrated with conservation of seagrass ecosystems which as sea cucumbers habitat and a proper maintenance system. Eight species of sea cucumbers, consist of 4 species of Holothuridae (Bohadschia bivittata, Actinopyga lecanora, Holothuria leucospilota, H. scabra), and 4 species Stichopodidae (Stichopus herrmanni, S. ocellatus, S. horren, S. monotuberculatus) have been identified and restocking in this area. The released biota can live and grow well and breed at the research site. The construction of seagrassbased sea cucumber ecosystem restocking system has become one of the new tourist attractions integrated with the Thousand Islands National Park tourist facilities, which are very attractive to visitors.
\end{abstract}

Keywords: ecosystem approach fishery managemen (EAFM), restocking, sea cucumbers fishery, seagrass ecosystem

\begin{abstract}
ABSTRAK
Kepulauan Seribu merupakan salah satu sentra penghasil teripang di Indonesia. Teripang merupakan salah satu komoditi ekspor perikanan dengan harga jual yang tinggi. Dalam dua dekade terakhir, tangkapan teripang telah menunjukkan penurunan tajam. Tingginya intensitas penangkapan dan degradasi habitat merupakan dua faktor utama yang mengancam keberlanjutan perikanan teripang. Salah satu upaya untuk pemulihan stok teripang melalui pendekatan ekosistem telah diujicobakan di wilayah Kepulauan Seribu, Jakarta. Tulisan ini mencakup aspek bio-teknis
\end{abstract}


upaya pemulihan perikanan teripang secara terintegrasi dengan pendekatan ekosistem. Upaya pemulihan dilakukan melalui beberapa tahap, yaitu studi status dan kelayakan habitat, penyiapan wadah pemeliharaan biota, penebaran benih, monitoring dan evaluasi. Sebelum kegiatan dilakukan, terlebih dahulu melakukan koordinasi dengan institusi lokal (Balai Taman Nasional Kepulauan Seribu). Hasil kajian menunjukkan bahwa upaya pemulihan perikanan teripang harus diselaraskan dengan upaya konservasi ekosistem lamun sebagai habitat teripang dan sistem pemeliharaan yang layak secara teknis. Delapan spesies teripang, terdiri dari 4 spesies Holothuridae (Bohadschia bivittata, Actinopyga lecanora, Holothuria leucospilota, H. scabra), dan 4 species Stichopodidae (Stichopus herrmanni, S. ocellatus, S. horren, S. monotuberculatus) telah terindentifikasi dan di-restocking di lokasi ini. Biota yang dilepas dapat hidup dan tumbuh dengan baik dan berkembangbiak di lokasi penelitian. Konstruksi sistem restocking teripang berbasis ekosistem lamun telah menjadi salah satu obyek wisata baru terintegrasi dengan fasilitas wisata Taman Nasional Kepulauan Seribu, yang sangat menarik bagi pengunjung.

Kata kunci: pendekatan ekosistem (EAFM), restocking, perikanan teripang, ekosistem lamun

\section{PENDAHULUAN}

Stok ikan di perairan dunia cenderung terus menurun selama 3 dasawarsa terakhir dengan meningkatnya permintaan pasar, khususnya di perairan pesisir. Sementara itu, pasokan dari kegiatan budidaya belum mampu memenuhi defisit kebutuhan tersebut. Pemanfaatan berlebihan (over exploitation) dan kerusakan habitat sumberdaya ikan merupakan dua faktor penyebab utama. Kondisi yang sama terjadi di wilayah perairan Indonesia. Bahkan beberapa jenis sumberdaya ikan tertentu, seperti teripang telah menunjukkan fenomena chronic-overfishing, yang secara alami tidak akan mampu lagi untuk pulih (Bell et al. 2008; Purcell et al. 2010).

Upaya pemulihan stok sumberdaya ikan diantaranya dilakukan melalui program pengayaan stok dan sea ranching. Taurusman (2013) menyatakan bahwa program pengayaan stok dan sea ranching telah diterapkan di berbagai negara dalam upaya memulihkan atau meningkatkan stok ikan alam. Beberapa upaya tersebut telah menunjukkan hasil yang nyata (significant) dalam memperbaiki suplai produk perikanan, seperti perikanan kerang di Belanda, udang dan kakap di Jepang, lobster dan kerang di Norwegia (Leber et al. 2004; Bell et al. 2005). Kegiatan sea ranching di perairan Indonesia telah dilakukan, diantaranya yaitu oleh Kurnia et al. (2013). Kegiatan sea ranching dilakukan di Perairan Semak Daun, berupa pelepasan ikan kerapu ke laut untuk ditangkap setelah mencapai ukuran konsumsi.

Teripang merupakan salah satu komoditi ekspor dengan pasar utama yaitu Eropa, Jepang, Singapura, Korea Selatan, dan Amerika. Negara pemasok utama teripang di pasaran internasional antara lain Indonesia, Hongkong, Filipina, Kaledonia Baru, Maldives, India, dan Srilanka (Albar et al. 2013). Terdapat 60 spesies teripang yang ditangkap dan dimanfaatkan oleh lebih dari 40 negara di dunia (FAO 2010). Bersumber dari SEAFDEC (2009) dalam (Perez \& Brown 2012), diketahui bahwa harga teripang di pasar ekspor berkisar antara 1,4 US\$ hingga 112,50 US\$. Harga tertinggi adalah teripang jenis Holothuria scabra dan Apostichopus japonicus, dan terendah adalah jenis Bohadschia marmorata.

Perkembangan ekspor teripang Indonesia meningkat setiap tahunnya. Ferdouse (2004) menyatakan bahwa, pada tahun 2000 Indonesia merupakan produsen terbesar ekspor teripang, yaitu mencapai 2.500 ton. Meningkatnya permintaan pasar Asia secara luas mendorong meningkatnya upaya eksploitasi teripang di berbagai negara penghasil (FAO 2010). Selain itu, sejak akhir tahun 1990-an eksploitasi teripang bertambah dengan adanya kegiatan riset produk alam dan penggunaan teripang sebagai hewan akuarium.

Kepulauan Seribu merupakan salah satu penghasil teripang yang potensial di Indonesia. Menurut Romimohtarto (1977) kegiatan penangkapan teripang mulai banyak dilakukan pada tahun 1973, seperti di Pulau Pari dimana dengan mudahnya dapat mengumpulkan sebanyak 14.000 spesimen teripang kapuk dalam waktu 2 pekan. Intensitas penangkapan teripang di Kepulauan Seribu terus meningkat dan terindikasi telah membahayakan bagi keberlanjutan sumberdaya teripang. Menurut Darsono (2007), berdasarkan lamanya eksploitasi teripang berlangsung, diduga bahwa populasi teripang mengalami tekanan yang cukup serius dan mengancam kelestariannya. Hal ini terjadi karena laju pertambahan (recruitment) tidak sebanding dengan laju pemanfaatannya. Penurunan populasi sumberdaya teripang dirasakan terjadi terutama terhadap jenis-jenis komersial 
seperti teripang pasir (Holothuria scabra) dan teripang susuan (Holothuria nobilis). Sekali kepadatan populasi teripang turun di bawah titik kritis, maka sangat sulit bagi populasi untuk pulih kembali. Albar et al. (2013) melalui hasil penelitiannya menyatakan bahwa produktivitas penangkapan teripang di Kepulauan Seribu berkisar antara 0,1-4,0 kg per trip, tergantung pada bulan penangkapannya. Intensitas penangkapan yang tinggi, telah menimbulkan permasalahan yaitu terkait dengan berkurangnya sumber daya teripang di daerah penangkapan.

Lamun memiliki peran yang sangat penting dalam mendukung suplai sumber protein ikan bagi manusia. Menurut Unsworth et al. (2018) terdapat manfaat langsung dan tidak langsung padang lamun bagi perikanan tangkap. Manfaat langsung lamun merupakan fishing ground bagi nelayan khususnya skala kecil untuk menangkap ikan terutama kelompok invertebrata (seperti teripang, udang dan kerang). Biota jenis ini ditangkap baik secara sederhana memungut dengan tangan secara langsung saat pasang surut atau dikenal dengan istilah 'gleaning' hingga menggunakan teknologi trawler. Manfaat tidak langsung atau manfaat secara ekologis lain lamun adalah sebagai habitat asuhan (nursery ground) dan pendukung rantai makanan (trophic subsidies) bagi ikan target tangkapan di perairan pesisir dan laut lepas (off-shore). Sekitar 746 species ikan di perairan Indo-Pacific dan $21,5 \%$ dari 25 jenis ikan tangkapan utama dunia yang dilaporkan FAO pada tahun 2016 berasosiasi dengan ekosistem lamun (Unsworth et al. 2018). Di perairan Timur Indonesia, lebih dari 100 spesies ikan tangkapan yang didaratkan merupakan jenis-jenis ikan yang berasosiasi dengan padang lamun (Unsworth et al. 2014). Walaupun memiliki fungsi yang sangat penting bagi suplai perikanan tangkap, hingga saat ini habitat lamun belum diperhitungkan dalam kebijakan pengelolaan perikanan pada tingkat lokal, nasional, bahkan global (e.g. Unsworth et al. 2018).

Begitu juga dengan padang lamun di Kepulauan Seribu, memiliki fungsi ekologis yang sangat penting dalam mendukung suplai ikan target tangkapan, khususnya teripang dan jenis perikanan invertebrata lainnya. Hasil penelitian Taurusman et al. (2013) terdapat delapan species lamun yang ditemukan di perairan Kepulauan Seribu (stasiun pengamatan Pulau Pramuka dan Pulau Kelapa Dua), yakni Thalassia hemprichii, Cymodocea rotundata, Cymodocea serrulata, Halophila ovalis, Enhalus acoroides, Halodule uninervis, Halo- dule pinifolia, dan Halophyla minor. Kualitas ekosistem lamun di Kepulauan Seribu mengalami penurunan yang cukup nyata selama dua dekade terakhir. Berkembangnya kegiatan manusia di Kepulauan Seribu, seperti kegiatan pariwisata, permukiman dan aktivitas lainnya memungkinkan adanya pengaruh terhadap ekosistem lamun, sehingga diduga mengalami perubahan fisik, kelimpahan maupun sebarannya. Hal ini akan mengancam keberlanjutan suplai ikan tangkapan mengingat fungsi ekosistem lamun yang sangat penting bagi perikanan.

Pengelolaan perikanan teripang di Indonesia sangat terbatas dilakukan. Untuk itu, perlu dikembangkan pola pengelolaan yang berkelanjutan dengan melindungi sumberdaya dan pengendalian usaha eksploitasinya yang jika dibiarkan dapat mengancam kepunahan plasma nutfah. Fungsi ekologis dan fungsi ekonomis teripang diharapkan berjalan seiring. Dengan demikian kelestarian sumberdaya teripang mempunyai dua aspek, melindungi keberadaan sumberdaya dan menjaga keberlanjutan perikanannya. Sebagaimana yang diamanatkan oleh FAO (2003) tentang Pengelolaan Perikanan dengan Pendekatan Ekosistem (EAFM), pengelolaan perikanan berupa tindakan pengendalian input (sistem perizinan, intensitas pemanfaatan), dan pengendalian output (kuota tangkapan, waktu penangkapan, ukuran layak tangkap), ditujukan untuk mencegah terjadinya tangkap lebih (Adams 1993). Tindakan pengelolaan lainnya untuk melestarikan sumberdaya teripang adalah dengan pengayaan stok (stock enhancement), bahkan pemulihan stok (restocking) terhadap jenis-jenis target, dan produksi teripang yang berbasis budidaya (Battaglene 1999, Taurusman, 2012). Tindakan pengelolaan ini harus dilakukan secara terintegrasi dengan memperhitungkan struktur dan fungsi ekosistem terkait biota teripang target.

Menyikapi kondisi tersebut di atas, tim peneliti FPIK-IPB telah melakukan serangkaian kajian terkait konservasi dan rehabilitasi ekosistem pesisir, khususnya habitat lamun yang telah dilakukan oleh autor utama mulai tahun 2009 melalui kerjasama antara Pusat Kajian Sumberdaya Lautan (PKSPL IPB), Kementerian Negara Lingkungan Hidup dan Balai Taman Nasional Kepulauan Seribu (BTNKS), serta dukungan pendanaan riset dari hibah Direktorat Pendidikan Tinggi. Beberapa kajian terkait yang sudah dilakukan dan dipublikasikan antara lain: 1) Model restorasi ekosistem lamun (seagrass) dan restocking teripang dengan 
pendekatan partisipatif: suatu program riset aksi di Pulau Seribu, Jakarta (Taurusman et al. 2009), 2) Pendekatan terpadu pengayaan stok dan sea ranching untuk menjamin keberlanjutan sumberdaya perikanan tangkap (Taurusman et al. 2012), 3) Pemulihan dan restorasi habitat teripang: status ekosistem lamun di lokasi restocking Pulau Pramuka dan Pulau Kelapa Dua, Kepulauan Seribu, Jakarta (Taurusman et al. 2013), 4) DNA barcoding reveals vulnerable and not evaluated species of sea cucumbers (Holothuroidea and Stichopodidae) from Kepulauan Seribu reefs, Indonesia (Maduppa et al. 2017). Selain itu juga telah dihasilkan paket teknologi berupa "Desain Konstruksi Sea Pen Teripang" dipublikasikan pada Buku Teknologi Tepat Guna untuk Pemberdayaan Masyarakat tahun 2010, oleh Direktorat Pemberdayaan Masyarakat Pesisir dan Pengembangan Usaha, Ditjen KP3K, KKP. ISBN 978-979-19088-4-9. Pada tahun 2018, kembali dilakukan kajian terkait dengan pemulihan sumberdaya teripang, abalon, dan perikanan baronang dalam rangka peningkatan ketahanan pangan bagi masyarakat pulau kecil. Artikel ini menyajikan sebagian hasil terkini penelitian tersebut yakni "Integrasi Pemulihan Suplai Teripang melalui pendekatan Ekosistem di Taman Nasional Kepulauan Seribu" yang dilakukan bekerjasama dengan Balai Taman Nasional Kepulauan Seribu. Makalah ini bertujuan untuk memulihkan stok perikanan teripang berbasis ekosistem lamun yang diintegrasikan dengan promosi konservasi perikanan melalui pengembangan obyek wisata bahari di Taman Nasional Kepulauan Seribu.

\section{METODE}

Upaya pemulihan stok teripang yang terintegrasi dengan kegiatan konservasi dan wisata bahari dilakukan di Taman Nasional Kepulauan Seribu (TNKpS). Pemilihan lokasi ini sesuai dengan tujuan penelitian, dan telah mendapatkan dukungan dari Kepala Balai TNKpS. Bahan dan metode kajian seperti dideskripsikan pada Tabel 1. Upaya pemulihan stok teripang melalui restoking dilakukan melalui beberapa tahap kegiatan, yaitu koordinasi dengan Institusi TNKpS, studi kelayakan habitat, penyiapan wadah pemeliharaan, penebaran benih, monitoring dan evaluasi (Gambar 1).

\section{HASIL}

\section{Koordinasi dengan Institusi TNKpS}

Koordinasi telah dilakukan dengan pihak Institusi TNKpS dalam hal ini adalah Balai TNKpS. Kepala Balai TNKpS menyambut baik upaya yang dilakukan oleh Tim Peneliti dan mengalokasikan tempat di TNKpS sebagai lokasi untuk restocking teripang yang juga merupakan promosi konservasi dan menjadi obyek wisata. Pada saat ini telah dipasang papan nama di lokasi tersebut sebagai bentuk kerjasama antara Balai TNKpS dengan Tim Peneliti dalam hal ini berada di Institusi Fakultas Perikanan dan IImu Kelautan IPB dan Pusat Kajian Sumberdaya Pesisir dan Lautan IPB (Gambar 2).

Tabel 1 Jenis data, metode pengambilan data dan analisis data

\begin{tabular}{lll}
\hline Tujuan & Tahapan Kegiatan & Metode dan Analisis Data \\
\hline Memulihkan stok teripang & Pemilihan lokasi dan evaluasi & Kualitas dan kesesuaian habitat \\
berbasis ekosistem lamun & status kelayakan habitat lamun & lamun untuk pemeliharaan \\
yang diintegrasikan dengan & (Seagrass - world method) & teripang \\
promosi konservasi & Desain dan konstruksi sistem & Kesesuaian kontruksi dan material \\
perikanan melalui & pemeliharaan biota & yang digunakan \\
pengembangan obyek & Pemilihan dan pengadaan benih & Kesesuaian ukuran benih dan \\
wisata bahari di Taman & teripang & jenis yang ditebar \\
Nasional Kepulauan Seribu & Transportasi dan penebaran & Penanganan benih dan teknik \\
& benih & penebaran yang tepat \\
& Monitoring dan evaluasi & Keberlangsungan hidup, \\
& pertumbuhan dan & pertumbuhan, dan \\
& perkembangbiakan biota & perkembangbiakan biota \\
& ldentifikasi dan pengembangan & Data jumlah pengunjung wisata \\
& obyek wisata & \\
\hline
\end{tabular}




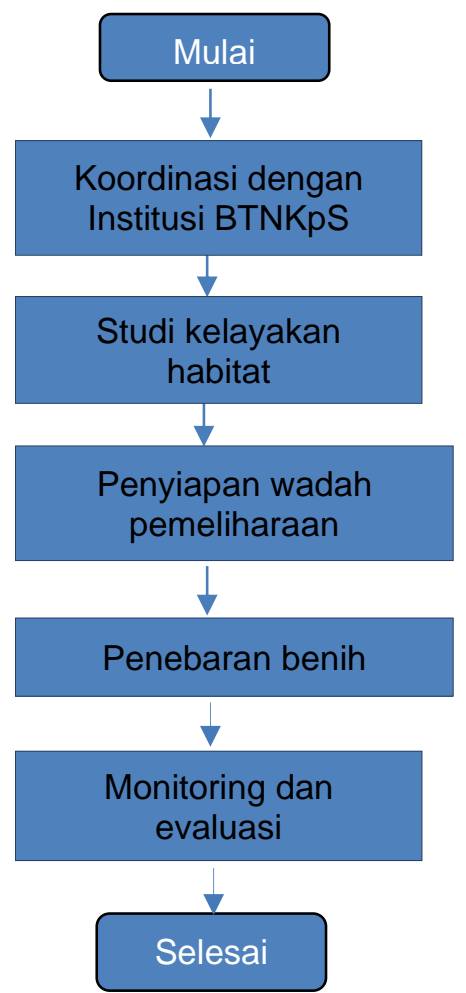

Gambar 1 Tahap upaya pemulihan stok teripang alam

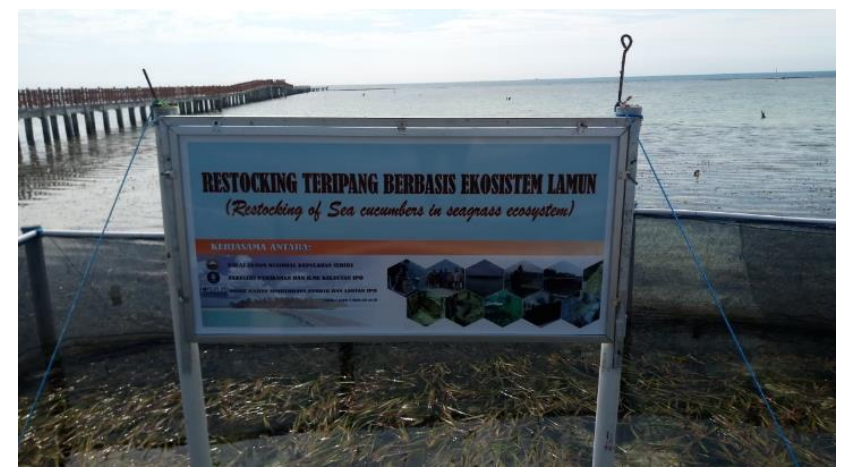

Gambar 2 Papan nama kerjasama institusi di lokasi restocking teripang berbasis ekosistem lamun

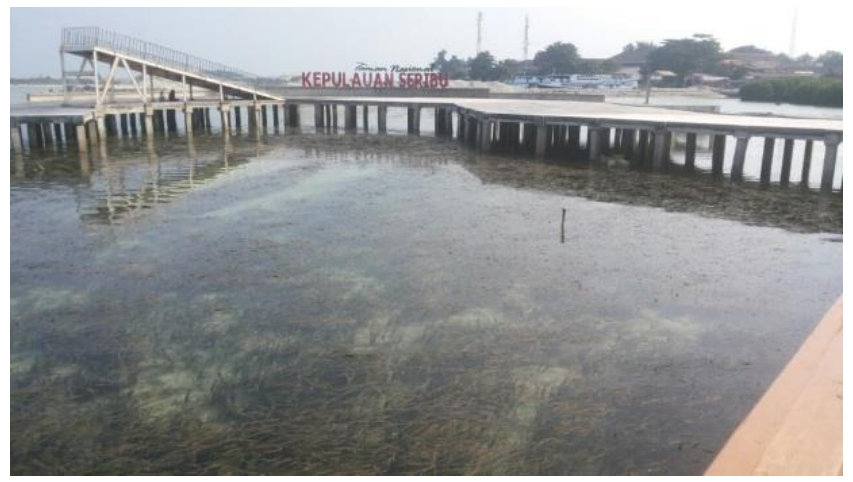

Gambar 2 Kondisi padang lamun yang dievaluasi statusnya sebelum dilakukan kontruksi wadah budidaya 


\section{Studi Kelayakan Habitat}

Pengukuran status ekosistem lamun dilakukan pada Bulan April-Juni 2018, pada lokasi yang terlihat pada Gambar 2. Gambar 2 menunjukkan foto lokasi pembangunan sistem pemeliharaan teripang dan abalon yang merupakan site wisata (tracking pasang surut) di $\mathrm{Pu}$ lau Pramuka yang dibangun oleh Balai TNKpS.

Berdasarkan hasil pengukuran penutupan lamun di lokasi studi dengan menggunakan metode seagrass watch berkisar antara 1-100\%, dengan rata-rata sekitar $41,3 \%$. Kriteria kesehatan lamun berdasarkan Kepmen LH No.200 tahun 2004 bahwa penutupan lamun di atas secara umum diklasifikasi sebagai 'kurang sehat' (luas penutupan antara 30$59 \%$ ). Walaupun pada beberapa titik pengukuran persen penutupan lebih dari $60 \%$ atau dengan kriteria 'sehat'. Penutupan lamun yang tinggi pada suatu habitat sangat penting bagi biota yang berasosiasi dengan habitat lamun tersebut, termasuk teripang. Gambar 3 menun-jukkan kondisi padang lamun yang dievaluasi statusnya sebelum dilakukan kontruksi wadah budidaya.

Hasil pengukuran menunjukkan tumbuhan lamun jenis Thalassia hemprichii mendominasi $(20,7 \%)$ jenis lamun yang hidup pada habitat tersebut, diikuti jenis Enhalus acoroides $(11,6 \%)$, dan Halodule uninervis $(6,9 \%)$. Jenisjenis lamun lainnya yang ditemukan di lokasi ini adalah Cymodocea rotundata, Cymodocea serrulata, Halophila ovalis, dan Syringodium isoetifolium. Karena ukuran tanaman yang relatif besar, daun yang panjang dan lebar, serta rimpang yang besar dan kuat, dominannya jenis lamun $E$. acoroides pada lokasi ini sangat mendukung bagi kehidupan biota teripang, kerang dan abalon yang dipelihara. Teripang memanfaatkan serasah daun lamun sebagai makanan. Kehadiran mikorganisme yang hidup berasosiasi dengan lamun juga merupakan sumber makanan bagi teripang yang bersifat filter feeders dan deposit feeders.

Menurut van Katwijk et al. (2011) kualitas kesehatan ekosistem lamun dapat dievaluasi pada tiga tingkatan (level). Pertama, tingkat individu, yakni aspek fisiologi dan morfologi tanaman, seperti panjang dan jumlah daun. Kedua, tingkat komunitas yang meliputi komposisi spesies lamun dan struktur komunitas makrozoobenthos. Ketiga, tingkat landscape seperti persen penutupan. Lebih lanjut dijelaskan bahwa persen penutupan, biomassa bagian atas permukaan, panjang dan lebar daun meningkat pada fase awal gangguan (disturbance) khususnya akibat eutrofikasi dan selanjutnya menurun ketika tingkat eutrofikasi semakin mencapai level yang tinggi (severe). Perubahan komposisi spesis seiring dengan perubahan tingkat pencemaran organik.

Berdasarkan analisis habitat lamun, maka dapat disimpulkan bahwa lokasi ini cocok untuk kegiatan pemeliharaan teripang dan abalone, serta biota lainnya yang berasosisasi dengan ekosistem lamun, seperti ikan baronang dan kuda laut. Di samping itu, dengan adanya fasilitas tracking wisata pada daerah pasang surut di bagian timur Pulau Pramuka yang telah dibangun oleh Balai Taman Nasional Kepulauan Seribu (BTNKS), maka hasil penelitian tentang status ekosistem lamun ini sangat bermanfaat sebagai baseline informasi dan sebagai salah satu obyek wisata utama di lokasi ini.

\section{Penyiapan Wadah Pemeliharaan Biota}

Pembuatan wadah pemeliharaan biota (demplot sea pen culture) (Gambar 4) merupakan hasil ujicoba yang telah dievaluasi desainnya, diperbaiki (improve) dan dikembangkan di TNKpS. Wadah diperuntukkan untuk dapat menjadi tempat pemelihraan bagi jenis teripang, kerang, dan gastropoda (abalon). Wadah pemeliharaan induk dan pembesaran teripang merupakan hasil penelitian sebelumnya (Taurusman 2010; 2012; 2013; 2014; 2016) yakni berbentuk bujur sangkar yang terbuat dari jaring yang diperkuat dengan kayu, dengan ukuran 13 meter panjang, 13 meter lebar dan 2 meter tinggi. Untuk memperkuat dan mencegah lolosnya biota target, maka dibuat tiga lapis jaring mulai dari mesh size terkecil hingga 1 inchi di bagian luar.

Berdasarkan hasil penelitian pada tahap sebelumnya, keterbatasan bahan baku kayu diatasi dengan mencoba menggunakan bahan pipa plastik (PVC, Polyvinyl Chloride) yang diisi dengan material semen. Secara teknis konstruksi ini lebih kuat dari sebelumnya yang menggunakan kayu. Di sisi lain, penebangan kayu di pulau kecil pada lokasi studi ini seperti di Pulau Seribu akan berpotensi merusak kawasan konservasi di Pulau Seribu.

\section{Penebaran benih}

Benih teripang yang ditebar berasal dari hatchery atau benih alam yang direlokasi dari tempat lain. Sebelum penebaran, kualitas benih dikontrol dengan baik untuk mencegah penye- 


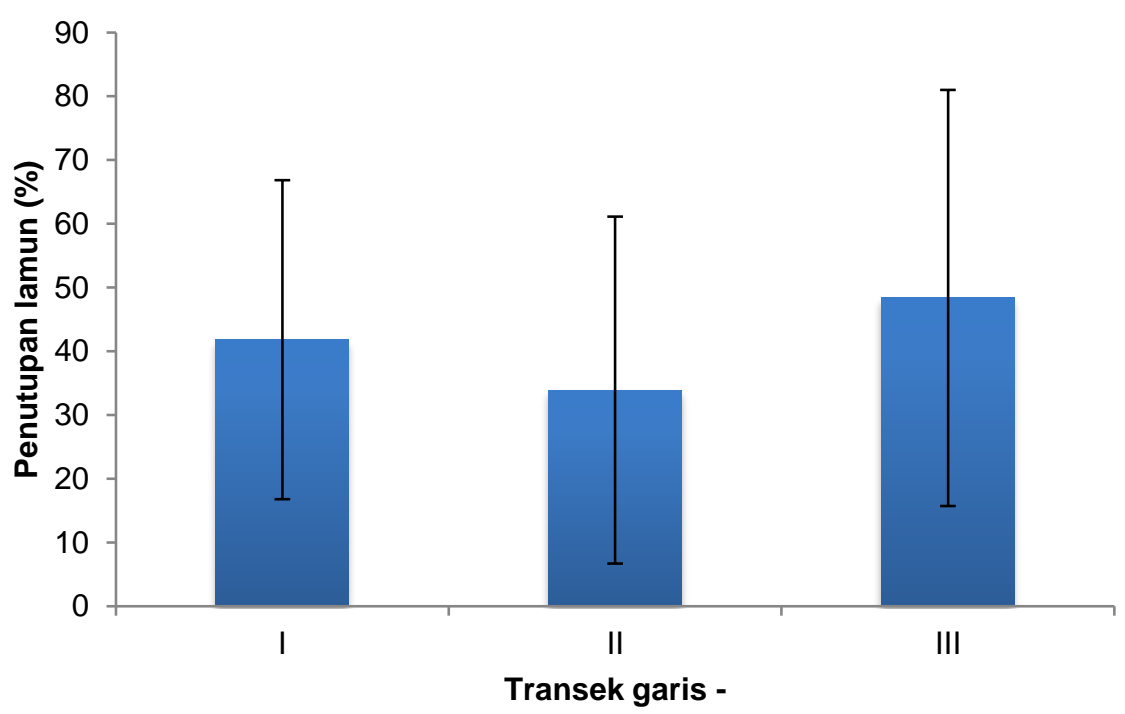

Gambar 3 Grafik persen penutupan lamun pada lokasi penelitian

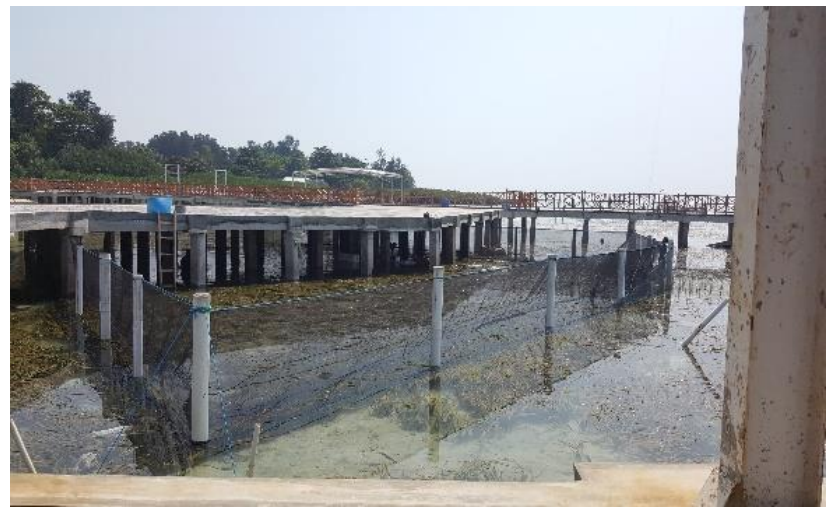

Gambar 4 Kontruksi sistem pemeliharaan berbasis ekosistem lamun berupa jaring tancap untuk biota teripang dan abalone di Pulau Pramuka

baran penyakit dan parasit. Pelepasan benih, baru dilakukan bila habitat sudah dalam kondisi yang layak atau mendukung kehidupan juvenil yang dilepas.

Benih teripang pasir yang ditebar berasal dari unit pembenihan Balai Besar Riset Budidaya Laut dan Penyuluhan Perikanan, Kementerian Kelautan dan Perikanan, di Gondol, Bali. Benih kemudian ditransportasikan lewat udara pada malam hari dan dibawa ke Pulau Seribu pada pagi harinya. Diperlukan waktu total sekitar 12 jam transportasi terhadap benih teripang tersebut.

Terdapat dua ukuran benih yang ditebar, yakni 5-10 gram, dan 10-18 gram. Selanjutnya akan dilakukan monitoring secara reguler untuk mengevaluasi kelangsungan hidup, pertumbuhan, dan nantinya juga perkembangbiakan biota tersebut. Di samping benih yang berasal dari panti pembenihan, juga dilakukan penanaman benih teripang yang berasal dari lokasi sekitar di Kepulauan Seribu. Hal ini ditujukan untuk melakukan upaya pemulihan stok teripang di lokasi tersebut yang sudah diketahui berdasarkan penelitian sebelum sudah berada pada status "chronic-overfished". Dengan status ini peluang biota teripang di lokasi tersebut untuk melakukan rekruitmen sangat kecil, karena kepadatan induk yang sudah sangat kecil, kurang dari threshold of alle effect, yakni $10-$ 15 individu per hektar.

Selain benih teripang pasir (Holothuria scabra) yang telah didatangkan dari panti pembenihan, juga ditebarkan berbagai jenis teripang yang diperoleh dari alam. Terdapat delapan jenis teripang yang di-restocking di lokasi ini yakni 4 spesies Holothuridae (Bohadschia bivittata, Actinopyga lecanora, Holothuria leucospilota, H. scabra), dan 4 species Sticho- 
podidae (Stichopus herrmanni, S. ocellatus, S. horren, S. monotuberculatus).

\section{Monitoring dan Evaluasi}

Monitoring dan evaluasi dilakukan terutama untuk mengetahui manfaat (benefit) program dan kemungkinan dampak yang terjadi pada ekosistem. Keuntungan berupa perbaikan kualitas stok yang pada gilirannya memberikan manfaat pada masyarakat lokal. Sementara itu, kemungkinan dampak yang akan terjadi pada aspek genetik (e.g. Ward 2006), penyakit (e.g. Mushike and Muroga 2004), atau ekologis dari interaksi antara biota asal hatchery dan alam (Kaeriyama and Edpalina 2004) serta kemungkinan terhadap keseimbangan rantai makanan perlu dimonitor dan dievaluasi secara terprogram dengan menggunakan metode ilmiah terbaik yang dapat diterapkan.

Untuk mengantisipasi dampak negatif yang mungkin terjadi pada aspek genetik misalnya, maka Ward (2006) menyarankan agar induk yang digunakan pada hatchery untuk menghasilkan benih yang akan ditebar, seyogyanya berasal dari lokasi yang sama, serta dengan menggunakan sebanyak mungkin jumlah induk yang dipijahkan. Kalau pada lokasi yang akan ditebar tidak tersedia induk yang layak, maka induk yang digunakan harus diambil dari populasi yang paling mirip secara genetik dengan yang di lokasi program. Selanjutnya perlu terus dimonitor perkembangannya (Ward 2006).

Akhirnya, dari serangkaian upaya secara bertahap dan sistematis seperti yang diusulkan, dengan dukungan kajian ilmiah terbaik yang tersedia akan diperoleh pedoman yang sesuai untuk pelaksanaan program pengayaan stok dan sea ranching (best-practice guideline). Sehingga jika terlaksana maka diharapkan perbaikan suplai stok ikan tangkapan, habitat pemijahan, dan selanjutnya pendapatan nelayan meningkat.

\section{Promosi Konservasi Teripang dan Ekosistem Lamun melalui Integrasi dengan Wisata Bahari di Wilayah BTNKpS}

Pada saat ini kegiatan promosi konservasi dan wisata bahari di Kepulauan Seribu telah berkembang dengan baik. Khusus untuk Pulau Pramuka, dimana lokasi restoking teripang ini dilakukan, telah berkembang: wisata menyelam (scuba diving), snorkeling, memancing, dan wisata pendidikan yaitu mengunjungi tempat penangkaran penyu sisik dan mengunjungi makam Habib Ali serta makam Habib Hasan. Kondisi perairan yang tenang dan jernih serta panorama laut menjadi daya tarik alamiah bagi wisatawan. Panorama seperti pada saat matahari terbit dan terbenam menjadi daya tarik tersendiri. Pulau Pramuka memiliki fasilitas terbilang lengkap sebagai pusat pemerintahan di Kepulauan Seribu. Disini tersedia penginapan, rumah makan, rumah sakit, masjid, lapangan olahraga, dan lainnya. Akses menuju Pulau Pramuka dapat ditempuh dengan 3 pintu masuk sehingga memudahkan pengunjung sampai ke tujuan yaitu Marina Ancol, Muara Angke dan Muara Saban.

Keberadaan lokasi restoking di TNKpS telah didesain dengan baik dan membuka peluang wisata baru. Beberapa potensi obyek wisata yang dapat dikembangkan adalah 1) pengunjung dapat melihat langsung biota teripang, 2) satu biota teripang bisa disiapkan untuk dapat disentuh langsung oleh pengunjung, 3) pengunjung dapat berfoto di lokasi dengan pemandangan yang indah, 4) wisata edukasi untuk pengunjung pelajar dengan disiaplannya booklet informasi teripang,

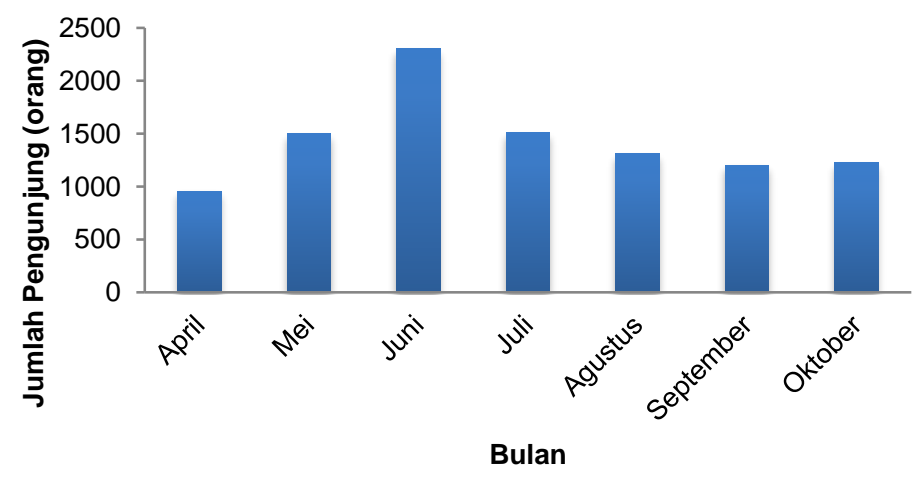

Gambar 5 Perkembangan jumlah pengunjung obyek wisata konservasi di Pulau Pramuka dimana sistem restocking teripang berbasis ekosistem lamun merupakan salah satu obyeknya 
lamun dan restoking. Sejak bulan April hingga Oktober 2018, obyek ini telah dikunjungi sebanyak 10.003 orang atau rata-rata 1429 orang per bulan (Gambar 5).

Promosi konservasi sumberdaya teripang dan ekosistem lamun melalui integrasi wisata bahari perlu dilakukan untuk meningkatkan kesadaran pihak-pihak terkait (stakeholders) perikanan teripang. Hal ini penting karena pemulihan stok perikanan teripang sangat ditentukan kesadaran pelaku, khususnya nelayan dalam memanfaatkan biota ini secara berkelanjutan. Lokasi ujicoba ini juga merupakan laboratorium alam untuk kegiatan pendidikan dan penelitian bagi pelajar dan mahasiswa.

\section{KESIMPULAN}

Upaya pemulihan perikanan teripang berbasis ekosistem lamun telah dapat diterapkan di Kepulauan Seribu, khususnya di perairan Pulau Pramuka dengan pendekatan terpadu. Upaya ini juga telah dapat diintegrasikan dengan promosi konservasi dan pengembangan wisata bahari, melalui kehadiran obyek wisata baru terkait dengan pemeliharan teripang dan biota lainnya yang berbasis ekosistem lamun.

\section{SARAN}

Perlu dilakukan proses lanjutan berupa monitoring secara reguler, pengembangan jumlah dan jenis biota target restocking, dan desiminasi hasil penelitian ini pada lokasi lain. Untuk mencapai tujuan pemulihan stok ikan tangkapan (dalam hal ini teripang), sistem ini perlu terus dikembangkan dan diadaptasikan sesuai dengan kondisi sistem alam dan sosial masyarakat pesisir setempat dengan dukungan institusi lokal.

\section{UCAPAN TERIMA KASIH}

Penulis mengucapkan terima kasih kepada Direktorat Jenderal Penguatan Riset dan Pengembangan, Kementerian Riset dan Pendidikan Tinggi yang telah mendanai kegiatan penelitian ini melalui skema Penelitian Terapan Unggulan Perguruan Tinggi (PTUPT) tahun anggaran 2018, dan Kepala serta Staf Balai Taman Nasional Kepulauan Seribu atas dukungannya.

\section{DAFTAR PUSTAKA}

Adams T. 1993. Management of Beche-de-mer (sea cucumber) Fisheries, Beche-demer, Info. Bull. 5: 13-16.

Albar Al, Nurani TW, Haluan J. 2013. Usaha Perikanan Teripang dan Pengembangannya di Kepulauan Seribu Provinsi DKI Jakarta. Buletin PSP. 21(3): 294-305.

Arifin, Jompa J. 2005. Studi Kondisi dan Potensi Ekosistem Padang Lamun sebagai Daerah Asuhan Biota Laut. Jurnal IImu-ilmu Perairan dan Perikanan Indonesia. 12(2): 73-79.

Azkab MH. 2000. Struktur dan Fungsi pada Komunitas Lamun. Oseana. 25(3): 9-17.

Battaglene SC. 1999. Culture of Tropical Sea Cucumber for Stock Restoration and Enhancement. Naga, the ICLARM Quarterly. 22(4): 4-11.

Bell JD, Purcell SW, Nash WJ. 2008. Restoring Small-scale Fisheries for Tropical Sea Cucumbers. Ocean and Coastal Management. 51: 589-593.

Darsono P. 2007. Teripang (Holothuroidea): Kekayaan Alam dalam Keragaman Biota Laut. Oseana. 32(2): 1-10.

Elfidasari D, Noriko N, Wulandari N, Perdana AT. 2012. Identifikasi Jenis Teripang Genus Holothuria Asal Perairan Sekitar Kepulauan Seribu berdasarkan Perbedaan Morfologi. Jurnal Al-Azhar Indonesia Seri Sains dan Teknologi. 1(3): 140-146.

Fajarwati SD, Setianingsih AI, Muzani. 2015. Analisis Kondisi Lamun di Pulau Pramuka, Kepulauan Seribu. SPATIAL Wahana Komunikasi dan Informasi Geografi. 13(1): 22-32.

FAO (Food and Agriculture Organization) of the United Nation. 2010. Putting Into Practice and Ecosystem Approach to Managing Sea Cucumbers Fisheries. Rome, FAO. 81 pp.

Ferdouse F. 2004. World Markets and Trade Flows of Sea Cucumber/Beche-de-mer. Sea. FAO fisheries technical paper. Roma: FAO. 101-131.

Perez ML, Brown EO. 2012. Market Potential and Challenges for Expanding The Production of Sea Cucumber in SouthEast Asia. di dalam: Hair CA, Pickering TD, Mills DJ, editor. Asia-Pacific Tropical Sea Cucumber Aquaculture;15-17 Febru- 
ary 2011; Noumea, New Caledonia; Australian Centre for International Agricultural Research (ACIAR). 177-188.

[KLH] Kementerian Lingkungan Hidup. 2004. Keputusan Menteri Negara Lingkungan Hidup Nomor 200 Tahun 2004.

Kurnia R, Suwardi K, Muchsin I, Boer M. Model Sea Ranching Ikan Kerapu Macan (Epinephelus suscoguttatus) di Perairan Semak Daun, Kepulauan Seribu. Jurnal Marine Fisheries. 4(1): 59-66.

Leber KM, Kitada S, Balnkenship HL, Svasand T. 2004. Stock Enhancement and Sea Ranching: Develompments, Pitfall, and Opportunities. Oxford (UK): Blackwell Publishing Ltd. HIm 562.

Mariana S, Bagaskara TbUN, Susdiyanti T. Kajian Pengembangan dan Pengelolaan Ekowisata Bahari di Pulau Pramuka Taman Nasional Kepulauan Seribu. Journal Nusa Sylva. 13(2): 48-55.

Maduppa H, Taurusman AA, Subhan B, Anggraini NP, Fadillah R, Tarman K. 2017. DNA Barcoding Reveals Vulnerable and Not Evaluated Species of Sea Cucumbers (Holothuroidea and Stichopodidae) from Kepulauan Seribu Reefs, Indonesia. Biodiversitas Journal. 18(3): $893-898$.

Purcell SW. 2010. Managing Sea Cucumber Fisheries with an Ecosystem Approach. in Lovatelli A, Vasconcellos M, Yimin Y, editor. FAO Fisheries and Aquaculture Technical Paper 520. Rome. FAO.

Romimohtarto K. 1977. Sumber Daya Bentik dari Pulau Pari dan Masalah-Masalahnya. Oseana. 3(4-5): 33-42.

Oktavianti R, Suryanti, Purwanti. 2014. Kelimpahan Echinodermata pada Ekosistem Padang Lamun di Pulau Panggang, Kepulauan Seribu, Jakarta. Diponegoro Journal of Maquares. 3(4): 243-249.
Orth RJ, Carruthers TJB, Dennison WC, Duarte CM, Fourqurean JW, Olyarnic S, Short FT, Waycott M, Williams SL. 2006. A Global Crisis for Seagrass Ecosystems. Bioscience. 56(12): 987-996.

Poejirahajoe E, Mahayani NPD, Sidharta BR, Salamuddin M. 2013. Tutupan Lamun dan Kondisi Ekosistemnya di Kawasan Pesisir Madasanger, Jelenga, dan Maluk Kabupaten Sumbawa Barat. Jurnal IImu dan Teknologi Kelautan Tropis. 5(1): 3646.

Purwati P, Syahailatua A (eds). 2008. Timun Laut Lombok Barat ISOI. Jakarta.

Taurusman AA, Isdahartati, Isheliadesti, Ristiani. 2013. Pemulihan dan Restorasi Habitat Teripang: Status Ekosistem Lamun di Lokasi Restocking Pulau Pramuka dan Pulau Kelapa Dua, Kepulauan Seribu, Jakarta. Jurnal IImu Pertanian Indonesia. 18(1).

Taurusman AA, Damar A, Adrianto L, Trihandoyono A. 2010. Model Restorasi Ekosistem Lamun (seagrass) dan Restocking Teripang dengan Pendekatan Partisipatif: Suatu Program Riset Aksi di Pulau Seribu, Jakarta. Prosiding Lokakarya Nasional I Pengelolaan Ekosistem Lamun, LIPI, PKSPL IPB, KKP \& KLH. Jakarta, 18 November 2009.

Taurusman AA. 2012. Pendekatan Terpadu Pengayaan Stok dan Sea Ranching untuk Menjamin Keberlanjutan Sumberdaya Perikanan Tangkap. Buletin PSP. 20(4): 441-450.

Unsworth RKF, Nordlund LM, Cullen-Unsworth LC. 2018. Seagrass Meadows Support Global Fisheries Production. Conservation Letters, Wiley Periodicals. Inc. 2018 (1-8). 